\title{
Effects of Ethylene Absorbent on Invertase Activity of Persimmon Fruit
}

\author{
Toshiyuki Matsui and Hirotoshi Kitagawa \\ Department of Agroindustrial Science, Faculty of Agriculture, \\ Kagawa University, Miki-cho, Kagazea 761-07
}

\begin{abstract}
Summary
An ethylene absorbent in a polyethylene bag containing persimmon fruit works effectively for extending the storage period. When persimmon fruit was stored in polyethylene bags with or without ethylene absorbent at room temperature or $5^{\circ} \mathrm{C}$, the effect was compared of invertase on sucrose in the fruit.

Invertase is considered to decline the quality of persimmon fruit during days of storage. Therefore, the activity of invertase was used as indications for the quality of the fruit.

The acid invertase in the soluble fraction of persimmon fruit showed higher activity in the non-use of the ethylene absorbent than in its use at room temperature and $5^{\circ} \mathrm{C}$, whereas that in the insoluble one had no significant differences. The activity of acid invertase in the soluble fraction was apt to be higher at room temperature of the nonuse of ethylene absorbent than at $5^{\circ} \mathrm{C}$ of $\mathrm{it}$, because the optimum temperature $\left(45^{\circ} \mathrm{C}\right.$ ) of invertase is closer to the room temperature than to $5^{\circ} \mathrm{C}$. It may be concluded that the ethylene absorbent can be used irrespective of the temperature to be used for storage of fruit, as it protects the decomposition of sucrose.
\end{abstract}

\section{Introduction}

'Fuyu', a typical non-astringent cultivar of persimmon fruit is harvested and shipped in the middle of October. As the persimmon fruit after harvest is deteriorated rapidly by softening and the degradation of sucrose, its shipment has to be concentrated at the same time, and then its cost tends to decline. Tarutani (12) was successful in extending the storage period of persimmon fruit by using polyethylene bags. Furthermore, Maotani et al.(7) had a further extention of the storage time of persimmon fruit in polyethylene bags with an ethylene absorbent. Invertase is considered to decompose sucrose of persimmon fruit into glucose and fructose after harvest and decline the quality of Persimmon fruit according to days of storage. In order to confirm the change of activity ratio of soluble and insoluble fractions during storage, both fractions were separated and then the activity of invertase was analyzed in both fractions. The activity of invertase was Received for publication March $1 \overline{7}, \overline{1987}$ used as indications for the quality of the fruit. As there are differences in enzyme activity and components of individual sample fruit after harvest, the differences of samples were canceled by a random sampling and the testing differences of two variances were estimated on the basis of $F$-value $(3,5)$.

\section{Materials and Methods}

\section{Materials}

A persimmon cultivar ' $F u y u$ ' was harvested in the field of Kagawa University located in Nagao, Kagawa Prefecture on 25th of October, 1985. After harvest disordered and deformed fruits were removed, and samples were drawn from the rest at random for the following experiment.

Each $10 \mathrm{~kg}$ of persimmon fruit was placed in a polyethylene bag of $0.05 \mathrm{~mm}$ in thickness (size $130 \times 85 \mathrm{~cm}$ ) and the bags were degassed. "Crisper 101", an ethylene absorbent coated with bromide on activated carbon was obtained from Ohoe Chemical Co. The conditions used for the storage were as follows; ER: $10 \mathrm{~kg}$ of fruit containing ethylene absorbent 
(about $38 \mathrm{~g}$ ) were stored in the polyethylene bag at room temperature. NER: The conditions are the same as ER except that the ethylene absorbent was not used. E5: The conditions are the same as ER except at $5^{\circ} \mathrm{C}$. NE5: The conditions are the same as E5 except that the ethylene absorbent was not used.

\section{Enzyme extraction}

The sample of stored fruits was mixed with $15 \%$ of Polyclar AT against total sample weight and the mixture was ground in a cooled motar and pestle with twice volume of chilled water and $5 \mathrm{~g}$ of sea sand(8). The resulting homogenate was filtered through 4 layers of cotton cloth and the filtrate was centrifuged at $6,000 \mathrm{G}$ for $10 \mathrm{~min}$. The supernatant was dialyzed with $5 \mathrm{mM}$ of phosphatecitrate buffer ( $\mathrm{pH} 7.4$ ) for $12 \mathrm{~h}$ and the fraction was named as soluble fraction (S. f.). On the other hand, the residue was re-extracted with twice volume of $0.2 \mathrm{M}$ phosphate-citrate buffer ( $\mathrm{pH} 8.0)$ for $12 \mathrm{~h}$ with occasional stirring. The resulting homogenate was centrifuged at $12,000 \mathrm{G}$ for $15 \mathrm{~min}$. The supernatant was dialyzed in the same way and the fraction was named as insoluble fraction (Is.f.). All procedures were followed at $4^{\circ} \mathrm{C}$.

\section{Enzyme assay}

The standard assay medium for acid invertase consisted of $0.2 \mathrm{ml}$ of $0.2 \mathrm{M}$ sodium phosphate citrate buffer $(\mathrm{pH} 5.0), 0.1 \mathrm{ml}$ of $1.5 \mathrm{M}$ sucrose, $0.1 \mathrm{ml}$ of water and $0.1 \mathrm{ml}$ crude enzyme. Blank experiment also runs with water instead of sucrose. The reaction mixture was incubated at $45^{\circ} \mathrm{C}$ for $15 \mathrm{~min}$. After neutralization, the reaction mixture was placed in ice, added to color producing reagents $(\mathrm{Cu}$-reagent) and boiled for $10 \mathrm{~min}$.

The reducing sugar was estimated by the method of Somogyi(10). Soluble protein was determined according to the method of Lowry et al.(6) using bovine serum albumin as the standard. The enzyme activity was represented as the amount of sucrose decomposed per min per mg protein.

4. Determination of sucrose, glucose and fructose by (i.C.

The sample was homogenized in Potter's homogenizer with 10 times volume at $90 \%$ of methyl alcohol, followed by filtration. The total extract was neutralized with $1 \mathrm{~N}$ sodium hydroxide and evaporated to a syrupy liquid under reduced pressure at $28-30^{\circ} \mathrm{C}$. The syrupy liquid was made up to $10 \mathrm{ml}$ with methyl alcohol.

\section{Conditions of G.C.}

To an aliquot $(0.1 \mathrm{ml})$ of alcoholic solution in a stoppered test tube was added $50 \mu \mathrm{l}$ of xylitol $(2 \mathrm{mg} / \mathrm{ml})$ as the internal standard, and the mixture was evaporated in vacuo. The dried sample was converted to trimethylsilyl derivative by the method of Brobst and Lott (1) with some modification as described here. It was dissolved in $100 \mu \mathrm{l}$ of pyridine, followed by mixing with $90 \mu 1$ of hexamethyldisilazane and $10 \mu l$ of trifluoroacetic acid. The test tube was then placed in a sonic bath for a tew minutes and allowed to stand at $50^{\circ} \mathrm{C}$ for $2 \mathrm{~h}$ with occasional sonification. The sugar derivative was analyzed by a Hitachi Model 263-30 gas chromatograph, fitted with a hydrogen flame ionization detector. The columns were of $1 \mathrm{~m} \times 3 \mathrm{~mm}$ i.d. glass packed with $5 ?$ Silicone OV-17, and $5 \%$ Silicone SE-30, respectively, on 60/80 mesh Chromosorb W (AWDMCS). The temperature of the columns were programmed from 140 to $250^{\circ} \mathrm{C}$ in the former case, and 180 to $2800^{\circ} \mathrm{C}$ in the latter case, at the rate of $5^{\circ} \mathrm{C} / \mathrm{min}$. Each compound in gas chromatogram was identified by comparison of the retention time with that of authentic compounds. Glucose, fructose and sucrose were determined from the standard curve made by the ratio of peak height for the internal standard.

\section{Results and Discussion}

\section{Total reeight and protein of persimmon} fruit during slorage

In order to investigate inclination of samples, testing differences of two variances of total weight was estimated. Table 1 shows the results of the testing. The samples drawn at random showed no inclination at every case. Fig. 1 shows total protein of persimmon fruit used for storage. It is well known that storage in polyethylene bags inhibits transpiration of fruits and polyethylene regulates concentrations of oxygen and carbon dioxide in conection with respiration(13). According to Tarutani (13), amounts of carbon dioxide and water vapor exhausted were comparably 
Table 1. Tests of difference of the two variances.

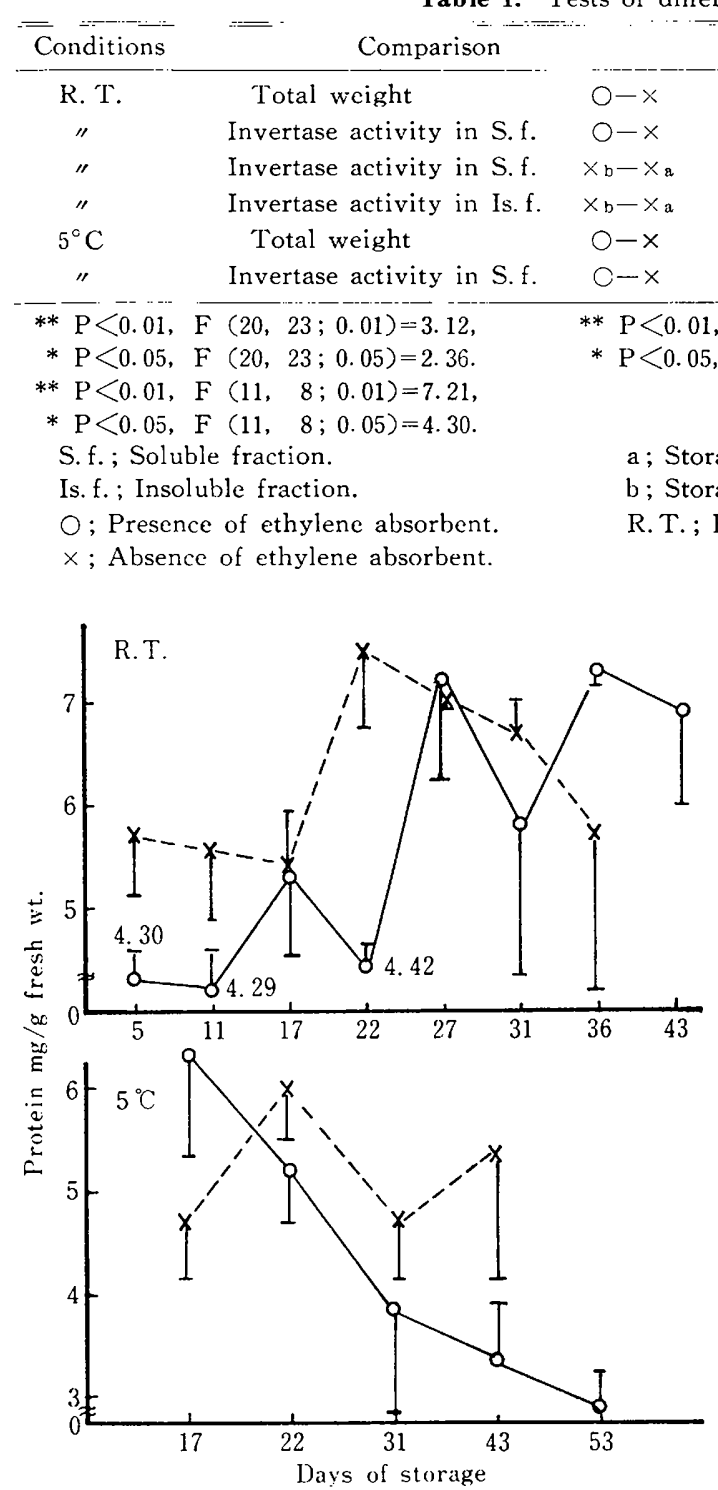

Fig. 1. Total protein of persimmon fruit used during storage. $\mathrm{O}-\mathrm{O}$, presence of ethylene absorvent : $x \cdots \times$, absence of ethylene absorbent. Values are means with S. E. $(n=3)$.

stable at lower temperature than $5^{\circ} \mathrm{C}$ but they fluctuated at higher temperature than $10^{\circ} \mathrm{C}$. The change of protein content of persimmon fruit during storage had no significant difference between $5^{\circ} \mathrm{C}$ and room temperature.

2. Changes of invertase activity of persimmon fruit during storage

The acid invertase has been reported to exist as bound and soluble forms in sugarcane(11,
14). The bound one located in the cell wall is combined tightly, whereas the soluble acid invertase is located in vacuoles(14). A possibility was suggested that some soluble enzymes are absorbed on the cell surface or cytoplasmic particles during the fractionation procedure (2). However, here the water soluble was defined as soluble fraction, whereas sodium phosphate-citrate buffer soluble was defined as insoluble fraction(4) in order to get easy fractionation. In the persimmon fruit, the acid invertase in the soluble fraction showed a higher activity than that in the insoluble fraction according to development of the fruit (9). Figs. 2 and 3 show the changes in invertase activity of persimmon fruit during storage at room temperature and at $5^{\circ} \mathrm{C}$, respectively. The activity of acid invertase in the soluble fraction increased rapidly at the initial stage without ethylene absorbent at room temperature, whereas that in insoluble one did slightly. The phenomenon may be explained thus: the deterioration of persimmon fruit increased initially due to the invertase activity in soluble fraction, and then due to that in insoluble fraction. The activity of acid invertase in the soluble fraction was apt to be higher at room temperature without ethylene absorbent than at $5^{\circ} \mathrm{C}$ of it, because the room temperature was considered to be closer to the optimum than $5^{\circ} \mathrm{C}$.

Finally, the acid invertase in the soluble fraction showed a higher activity in the nonuse of ethylene absorbent than in its use. It is considered that invertase activity may not 


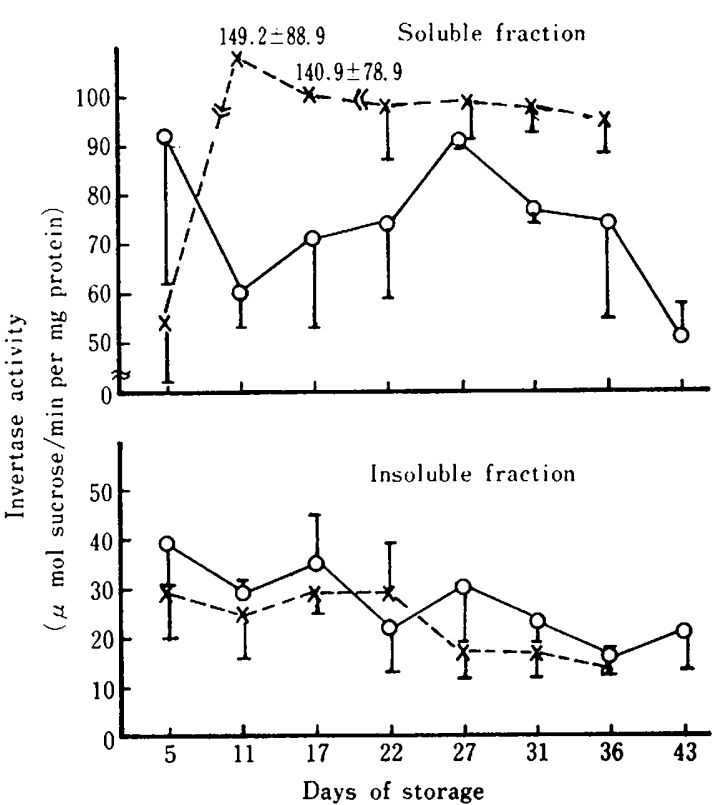

Fig. 2. Changes in invertase activity of persimmon fruit during storage at room temperature. Symbols as shown in Fig. 1.

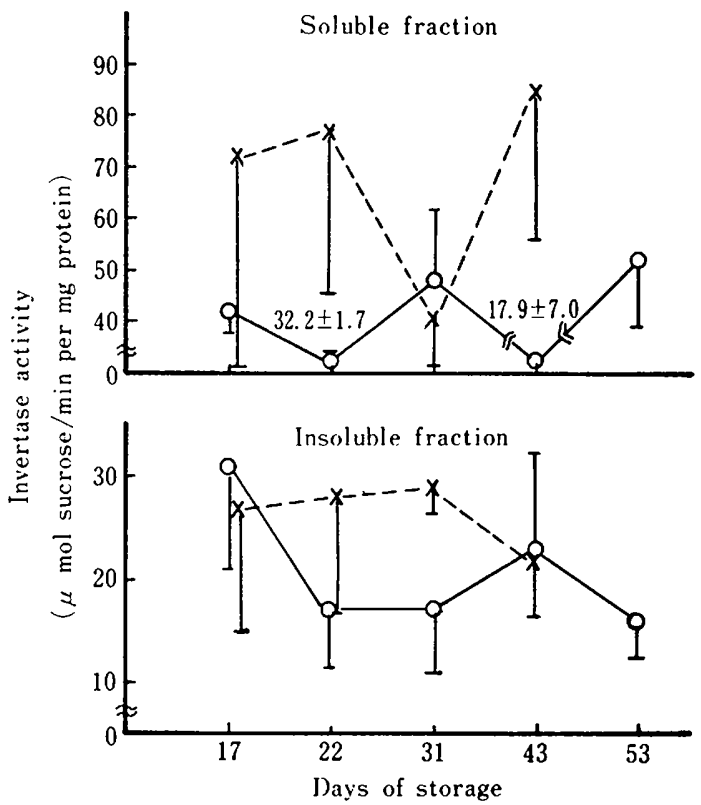

Fig. 3. Changes in invertase activity of persimmon fruit during storage at $5^{\circ} \mathrm{C}$. Symbols as shown in Fig. 1.

be increased as the ethylene generation was removed by the use of ethylene absorbent.

3. Changes in sucrose, glucose and fructose contents of persimmon fruit during

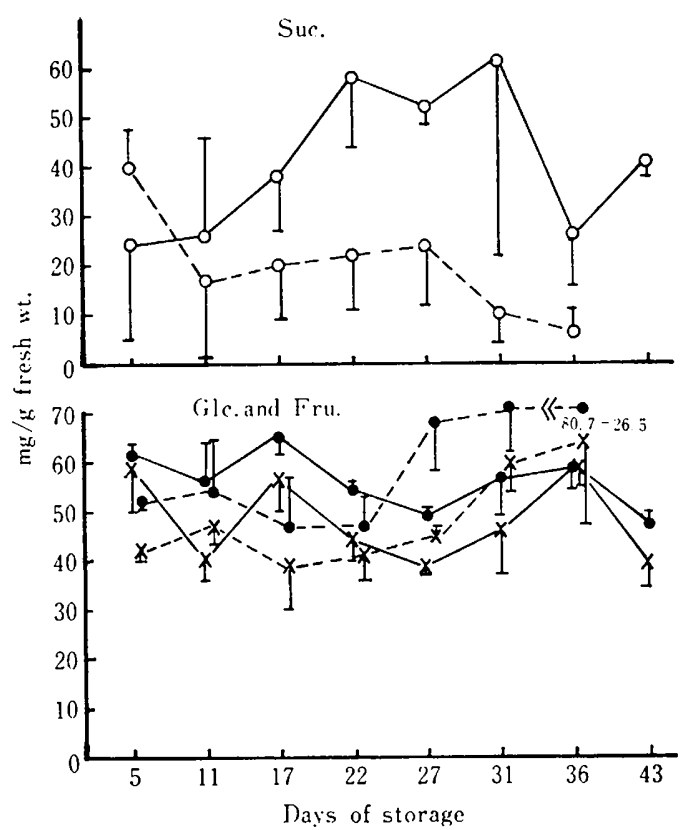

Fig. 4. Changes in carbohydrate contents of Persim mon fruit during storage at room temperature. -, presence of ethylene absorbent; $\cdots$, absence of ethylene absorbent; 0 , sucrose; glucose ; $x$, fructose.

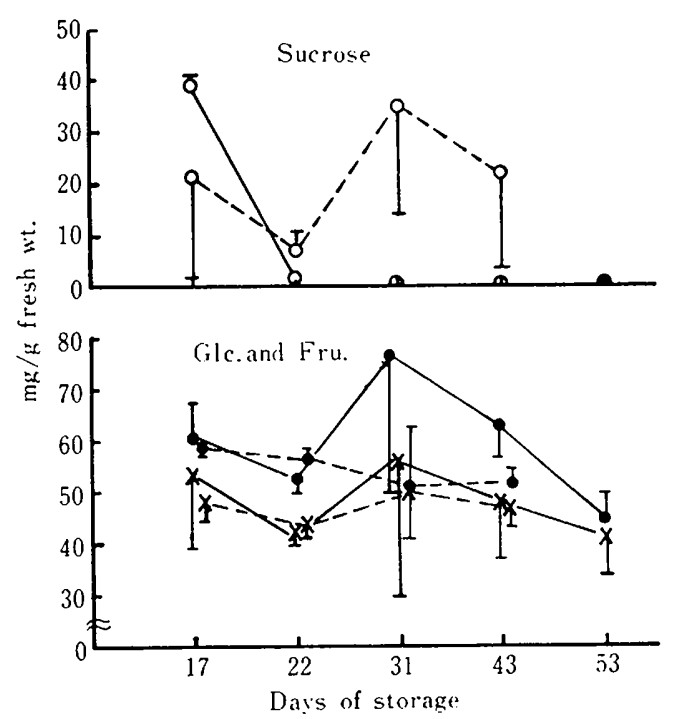

Fig. 5. Changes in carbohydrate contents of persimmon fruit during storage at $5^{\circ} \mathrm{C}$. Symbols as shown in Fig. 4.

storage

Figs. 4 and 5 show the changes in carbohydrate contents of persimmon fruits during preservation at room temperature and that at 


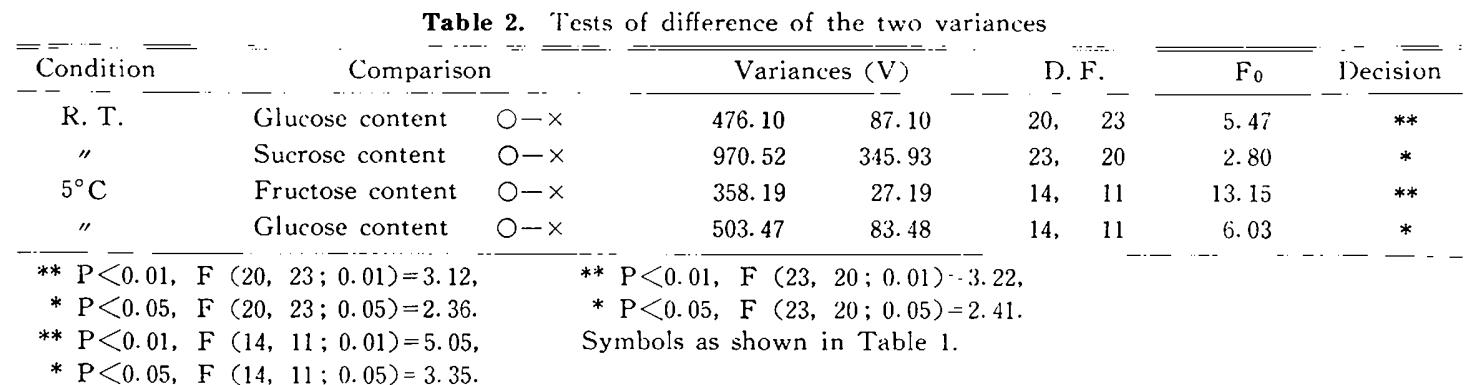

$5^{\circ} \mathrm{C}$, respectively. Table 2 shows testing differences of two variances of carbohydrates on the basis of F-value. Only sucrose and glucose contents showed significant difference at room temperature by the non-use of ethylene absorbent. Sucrose content was apt to decrease, whereas fructose and glucose decomposed by invertase were apt to increase. There was significant difference between the use and the non-use of ethylene absorbent in the fructose and glucose contents at $5^{\circ} \mathrm{C}$. In the persimmon, sucrose which serves as the substrate of invertase may be decomposed by the acid invertase at room temperature. In order to protect the persimmon from the decomposition of sucrose, it should be stored at a lower temperature. As the storage cost of persimmon, which amounts to large bulk, depends on the running cost for lower temperature, the use of an ethylene absorbent is considered to be valuable for extending the storage period at room temperature. Sucrose content was higher in the non-use of ethylene absorbent than in its use at room temperature. It may be concluded that the ethylene absorbent can be used irrespective of the temperature to be used for storage of fruit as it protects the decomposition of sucrose.

\section{Acknowledgement}

We wish to thank Prof. S. Kawamura of Kagawa-ken Meizen Junior College for his critical reading of this manuscript.

\section{Literature Cited}

1. Brobst, K. M. and C. E. Lott. Jr. 1966. Determination of some components in corn syrup by gas-liquid chromatography of the trimethylsilyl derivatives. Cereal Chem. 43: $35-43$.

2. IKI, K., H. NAKAGAWA and H. TAKEIIANA.
1977. Intracellular localization of $\beta$-fructo. furanosidase in tomato fruit tissue. Agric. Biol. Chem. 41: 1311-1312.

3. ISHIKAWA, K., T. FUJIMORI and K. KURUME. 1964. Statistical Methods. p. 23-24. Tokyo Kagaku Doojin, Tokyo (in Japanese).

4. KAto, T. and S. Kubota. 1978. Properties of invertase in sugar storage tissues of citrus fruit and changes in their activities during maturation. Physiol. Plant. 42: 6772.

5. Kishine, T. 1978. Statistics. p. 403-406. Yokendo, Tokyo (in Japanese).

6. Lowry, O. H., H. Rosebrough, A. I. FARR and R. RENDALL. 1951. Protcin measurement with Folin-phenol reagent. J. Biol. Chem. 193: 265-275.

7. Maotani, T., M. YAMAda and A. KuriHARA. 1982. Storage of Japanese persimmon of pollination constant non-astringent type in polyethylene bags with ethylene absorbent. J. Japan. Soc. Hort. Sci. 51: 195-202 (In Japanese with English summary).

8. Matsli, T. and H. KitagAwA. 1985. Seasonal changes of activities of invertases in relation to sugar accumulation in sugarcane. J. Japan. Soc. Food Sci. Technol. 32: 655660.

9. Matsui, T. and II. Kitagawa. 1986. Studies on carbohydrate of persimmon fruit. Abstr. Japan. Soc. Ilort. Sci. Autumn Meet., $440-441$.

10. Somogy i, M. 1952. Notes on sugar determination. J. Biol. Chem. 195: 19-25.

11. Sampietro, A. R., M. A. Battuone and F. E. PRADO. 1980. A regulatory invertase from sugar cane leaf-sheaths. Phytochemistry 19: $1637-1642$.

12. TARUTANi, T. 1960. Effect of some packing materials in the cold storage on the fruit quality of Fuyu variety. J. Japan. Soc. Hort. Sci. 29: 212-218. (In Japanese with English summary).

13. TARUtANi, T. 1965. Studies on the storage 
of persimmon fruits. Memories of Faculty of Agric. Kagawa Univ. 19:1-54

14. Vattuone, M. A. F., F. E. Prado and A.
R. SAmpietro. 1981. Cell wall invertase from sugar cane. Phytochemistry 20:189191.

\author{
エチレン吸収剤がカキ果実のインベルターゼ活性に与える影謐 \\ 松井 年行・北川 博敏

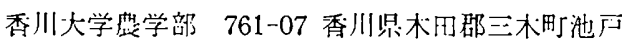

\begin{abstract}
摘要
エチレン吸収剂の入ったポリエチレン袋にカキ果実を たものより使用しなかった方がより离い活性を示した。 入れると，胋蔵期間の延长に非常に效果的である．果実 一方不溶性画分では有意差は認められなかった，可溶 を $5^{\circ} \mathrm{C}$ と室温でポエチレンバッグにエチレン吸収剂を 使った場合と伐わなかった場合，カキのショ精に拉ける 性画分の酸性インベルターゼ活性は，等温でェチレン吸 収剤を使わなかった方が $5^{\circ} \mathrm{C}$ の場合よりも活性が高かっ インベルターゼの効果について検封した．インベルター ゼは日数の経過につれて，カキ果尖の品質を低下すると 考えられている，従って，インベルターゼ活性をカキの 品質の指標之して使った，力キ果実の河浴性画分酸性1 た。これはインベルターゼの至適温度 $\left(45^{\circ} \mathrm{C}\right)$ が $5^{\circ} \mathrm{C}$ 上 りも室温に近いためと考えられた。

ショ糖の分解を保護するので，エチレン吸收剂は温度 に関係なく果実の販蔵に使われると考えられる。
\end{abstract}

